Keywords: Saltstone TCLP

Retention: Permanent

\title{
Saltstone 3QCY12 TCLP Results
}

R. E. Eibling

December 2012

Savannah River National Laboratory Savannah River Nuclear Solutions, LLC Aiken, SC 29808

Prepared for the U.S. Department of Energy under

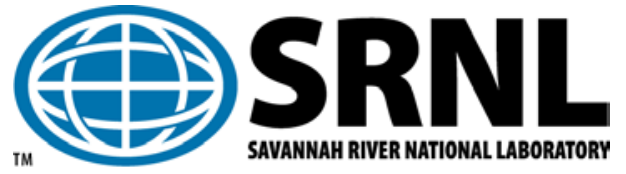
contract number DE-AC09-08SR22470. 
SRNL-STI-2012-00703

Revision 0

\section{DISCLAIMER}

This work was prepared under an agreement with and funded by the U.S. Government. Neither the U.S. Government or its employees, nor any of its contractors, subcontractors or their employees, makes any express or implied:

1. warranty or assumes any legal liability for the accuracy, completeness, or for the use or results of such use of any information, product, or process disclosed; or

2. representation that such use or results of such use would not infringe privately owned rights; or

3. endorsement or recommendation of any specifically identified commercial product, process, or service.

Any views and opinions of authors expressed in this work do not necessarily state or reflect those of the United States Government, or its contractors, or subcontractors.

\section{Printed in the United States of America}

Prepared for

U.S. Department of Energy 


\section{REVIEWS AND APPROVALS}

AUTHORS:

R. E. Eibling, Engineering Process Development

Date

TECHNICAL REVIEW:

M. M. Reigel, Engineering Process Development

Date

APPROVAL:

K. M. Fox, Manager

Date

Engineering Process Development

S.L. Marra, Manager

Date

Environmental \& Chemical Process Technology Research Programs

J. S. Contardi, Manager

Date

Saltstone Facility Engineering 
SRNL-STI-2012-00703

Revision 0

\section{EXECUTIVE SUMMARY}

A Saltstone waste form was prepared in the Savannah River National Laboratory (SRNL) from a Tank 50H sample and Z-Area premix material for the third quarter of calendar year 2012 (3QCY12). After a 34 day cure, samples of the saltstone were collected, and the waste form was shown to meet the South Carolina Hazardous Waste Management Regulations (SCHWMR) R.6179.261.24 and R.61-79.268.48(a) requirements for a nonhazardous waste form with respect to RCRA metals and underlying hazardous constituents. These analyses met all quality assurance specifications of USEPA SW-846. 


\section{TABLE OF CONTENTS}

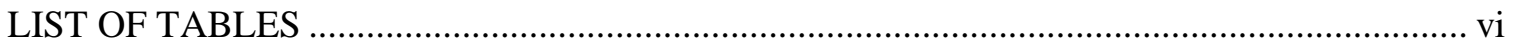

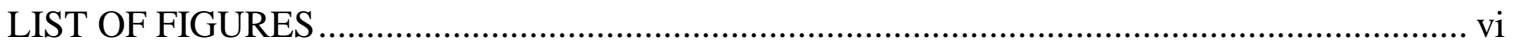

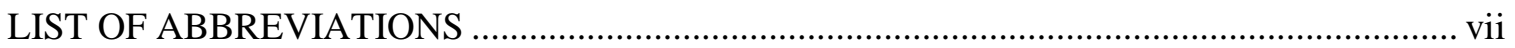

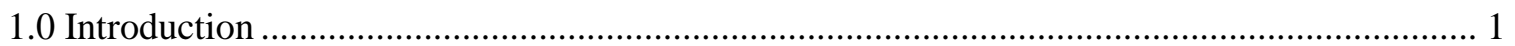

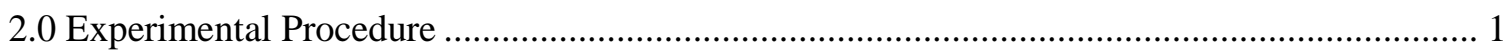

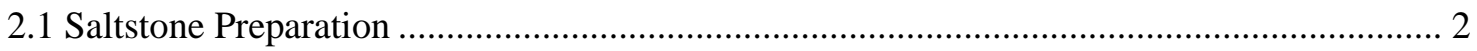

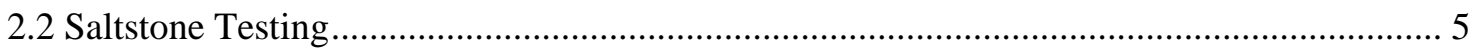

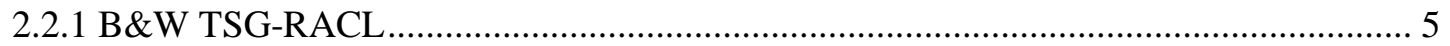

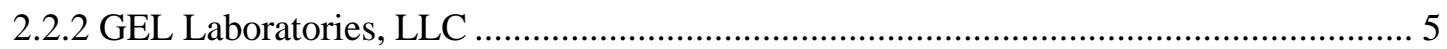

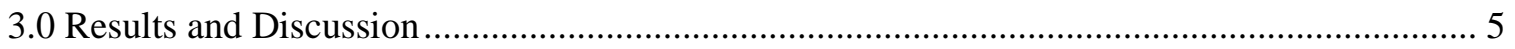

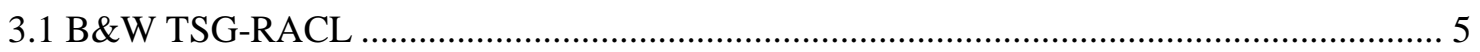

3.1.1 Comparison of Results to Regulatory Limits ............................................................ 6

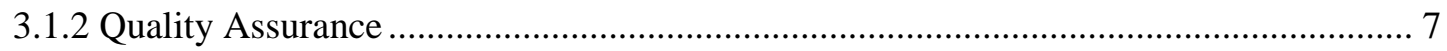

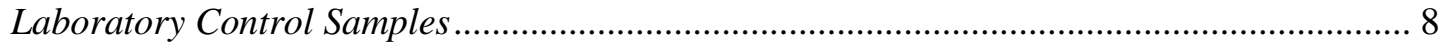

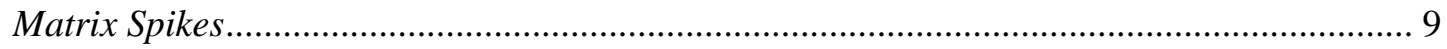

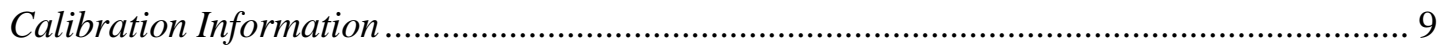

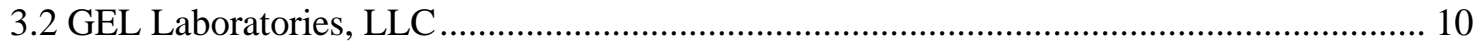

3.2.1 Comparison of Results to Regulatory Limits............................................................... 10

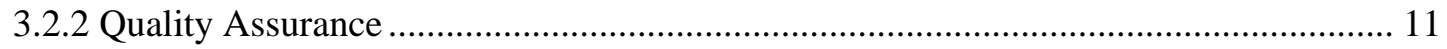

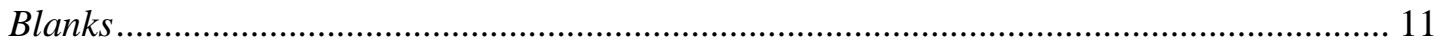

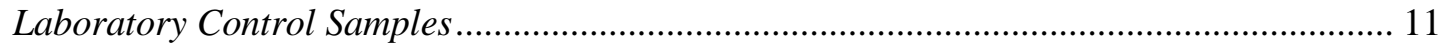

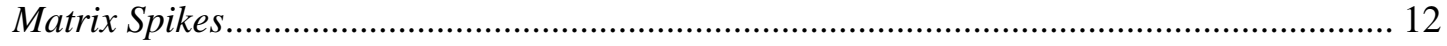

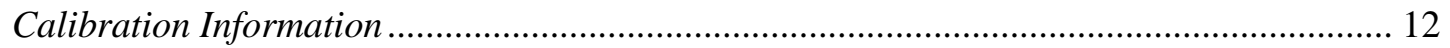

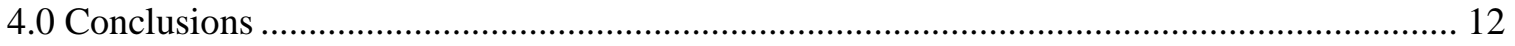

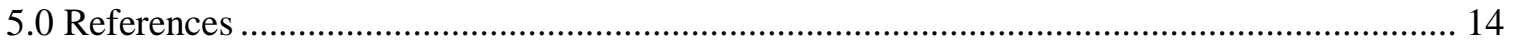




\section{LIST OF TABLES}

Table 2-1. Sample Results of TCLP Metals from Tank 50H WAC Analysis............................... 3

Table 2-2 Customer Recommended Values for Preparation of TCLP Sample .............................. 3

Table 3-1 TCLP Leachates RCRA Metal Concentrations, DLs, and QLs .................................. 6

Table 3-2 Saltstone TCLP Results and Corresponding Regulatory Limits .................................. 7

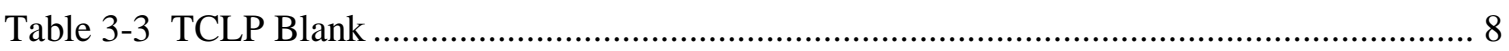

Table 3-4 RCRA Metal Laboratory Control Sample.................................................................... 8

Table 3-5 TCLP Leachates RCRA Metal Matrix Spike and Duplicate Results ............................ 9

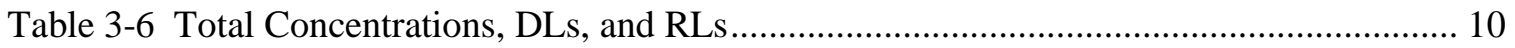

Table 3-7 Saltstone Total Results and Corresponding Regulatory Limits .................................. 11

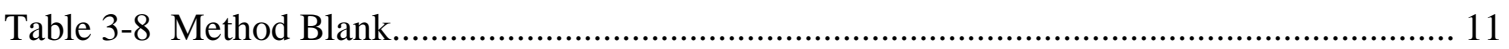

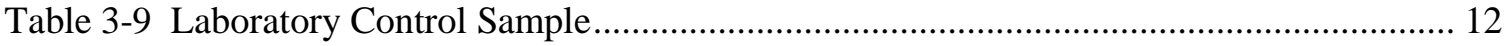

\section{LIST OF FIGURES}

Figure 2-1 Flowchart of Saltstone Preparation and Analysis ..................................................... 2

Figure 2-2 Data sheet for the Saltstone mix used to prepare the 3QCY12 TCLP sample ${ }^{5} \ldots \ldots . . . . . .4$ 


\section{LIST OF ABBREVIATIONS}

3QCY12 Third Quarter Calendar Year 2012

ARP Actinide Removal Process

B\&W TSG- $\quad$ B \& W Technical Services Group-Radioisotope and Analytical

RACL Chemistry Laboratory

CVAA Cold Vapor Atomic Absorption

DL Detection Limit

DSS-HT Decontaminated Salt Solution Hold Tank

EPA Environmental Protection Agency

ESS-WP Environmental Services Section - Waste Programs

ETP Effluent Treatment Project

ICP-MS Inductively Coupled Plasma - Mass Spectrometer

ISWLF Industrial Solid Waste Landfill

LCS Laboratory Control Sample

MCL Maximum Contaminant Level

MCU Modular Caustic Side Solvent Extraction Unit

MS Matrix Spike

MSD Matrix Spike Duplicate

QL Quantitation Limit

RCRA Resource Conservation and Recovery Act

RL Reporting Limit

RPD Relative Percent Differences

SCDHEC South Carolina Department of Health and Environmental Control

SCHWMR South Carolina Hazardous Waste Management Regulations

SDF Saltstone Disposal Facility

SDG Sample Delivery Group

SPF Saltstone Production Facility

SRNL Savannah River National Laboratory

SWLF Solid Waste Landfill

TCLP Toxic Characteristic Leaching Procedure

UHC Underlying Hazardous Constituent

UTS Universal Treatment Standards 
SRNL-STI-2012-00703

Revision 0

\subsection{Introduction}

The Saltstone Production Facility (SPF) receives waste from Tank $50 \mathrm{H}$ for treatment. Based upon a review of the daily waste transfer reports for the third quarter of the 2012 calendar year (3QCY12), Tank 50H accepted transfers of approximately $11 \mathrm{kgal}$ from the Effluent Treatment Project (ETP), approximately $1.3 \mathrm{kgal}$ from $211 \mathrm{H}$, approximately $1.3 \mathrm{kgal}$ from $221 \mathrm{H}$, approximately $84 \mathrm{kgal}$ from the Actinide Removal Process / Modular Caustic Side Solvent Extraction Unit (ARP/MCU) Decontaminated Salt Solution Hold Tank (DSS-HT), and approximately $12 \mathrm{kgal}$ from other sources.

The Saltstone Grout Sampling plan provides the South Carolina Department of Health and Environmental Control (SCDHEC) with the chemical and physical characterization strategy for the salt solution which is to be disposed of in the Z-Area Solid Waste Landfill (SWLF) ${ }^{\mathrm{i}}$. During operation, samples were collected from Tank $50 \mathrm{H}$ and grout samples prepared to determine the non-hazardous nature of the grout to meet the requirements of the South Carolina Hazardous Waste Management Regulations (SCHWMR) R.61-79.261.24(b) and R.61-79.268.48(a).

Savannah River National Laboratory (SRNL) was asked to prepare saltstone from samples of Tank 50H obtained July 17, 2012 during 3QCY12 to verify the non-hazardous nature of the grout. The samples were cured and shipped to Babcock \& Wilcox Technical Services GroupRadioisotope and Analytical Chemistry Laboratory (B\&W TSG-RACL) to perform the Toxic Characteristic Leaching Procedure (TCLP) ${ }^{\mathrm{ii}}$ and subsequent extract analysis on saltstone samples for the analytes required for the quarterly saltstone sample. In addition to the eight toxic metals-arsenic, barium, cadmium, chromium, mercury, lead, selenium and silver-analytes included the underlying hazardous constituents (UHC) antimony, beryllium, nickel, and thallium, which could not be eliminated from analysis by process knowledge ${ }^{i i i}$. B\&W TSG-RACL provided subsamples to GEL Laboratories, LLC for analysis for the UHCs benzene, phenols, and total and amenable cyanide.

\subsection{Experimental Procedure}

This section is a summary of the approach taken to prepare and characterize the saltstone samples. The saltstone sample preparation was performed at SRNL. Saltstone sample characterization was performed at both the B\&W TSG-RACL facility in Lynchburg, Virginia and the GEL laboratory facility in Charleston, South Carolina. Figure 2-1 is a flowchart of the steps taken to prepare and characterize the saltstone samples. 


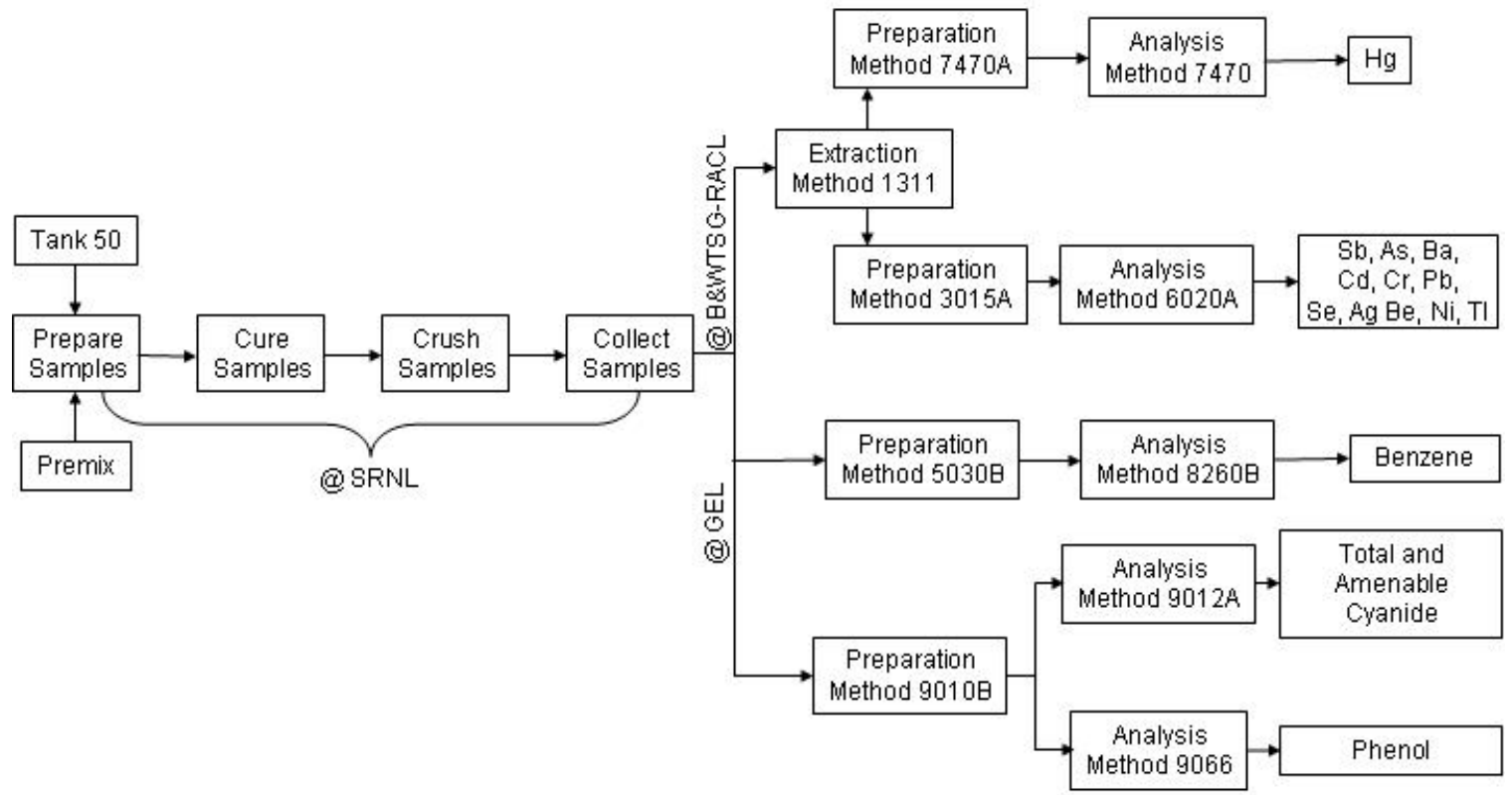

Figure 2-1 Flowchart of Saltstone Preparation and Analysis

\subsection{Saltstone Preparation}

Saltstone preparation was performed at SRNL. The weight percent solids data used for the TCLP sample were taken from the quarterly Waste Acceptance Criteria (WAC) analyses performed on Tank $50 \mathrm{H}^{\text {iv }}$. Table 2-1 lists the concentrations of TCLP metals of interest in the salt solution from the WAC analysis ${ }^{\text {iv }}$ for the sample. As shown in Table 2-1, the contents of Tank $50 \mathrm{H}$ exceed the regulatory limits for antimony, cadmium, chromium, mercury, and phenol, and therefore must be treated and disposed of in a non-hazardous waste form. Table 2-2 contains the parameters used to prepare the TCLP sample ${ }^{\mathrm{v}}$.

Saltstone samples for TCLP were prepared with the Tank $50 \mathrm{H}$ blended salt solution and a premix of cement, slag, and fly ash. Figure 2-2 shows the formulation used to prepare these samples. The admixtures were added to the salt solution first and then the dry feeds were added to the liquid. The salt solution, admixtures and premix materials were mixed for approximately three minutes using a paddle blade mixer. The mixing was paused for approximately five seconds after the initial 30 seconds of mixing to allow entrained air to escape from the grout. After the saltstone slurry was mixed, it was cast into a polyethylene zip top bag. The bag was laid flat and the air was expelled prior to sealing. The sample was cured flat in a polypropylene bag to facilitate the size reduction step needed to conform to the particle size requirements of the TCLP method.

After curing for not less than 28 days -34 days for the 3QCY12 sample, the saltstone was removed from the container and a portion of the saltstone was crushed and sieved to particles less than 0.9 centimeters ( $3 / 8$ inch) as prescribed by Section 7.13 of the TCLP method ${ }^{\text {ii }}$. The crushed saltstone was packaged into containers provided by Environmental Services Section - Waste Programs (ESS-WP). After the saltstone has been crushed, sieved and packaged, the sample is deemed "collected." vi ESS-WP retrieved the samples from SRNL and transported them to B\&W TSG-RACL for extraction and analysis. B\&W TSG-RACL repackaged a portion of the sample 
and shipped the subsample to GEL Laboratories to perform analysis for the UHCs benzene, phenol and total and amenable cyanide.

Table 2-1. Sample Results of TCLP Metals from Tank 50H WAC Analysis

\begin{tabular}{|c|c|c|}
\hline - & $\begin{array}{c}\text { Sample Results } \\
(\mathrm{mg} / \mathrm{L})^{\text {iv }}\end{array}$ & $\begin{array}{c}\text { Regulatory Limits } \\
(\mathrm{mg} / \mathrm{L})\end{array}$ \\
\hline- & 3Q12 & Toxicity $^{\mathrm{a}}$ \\
\hline As & $<0.0936$ & 5 \\
\hline Ba & $<0.826$ & 100 \\
\hline Cd & $<1.13$ & 1 \\
\hline $\mathrm{Cr}$ & 40.9 & 5 \\
\hline $\mathbf{P b}$ & 0.185 & 5 \\
\hline $\mathrm{Hg}$ & 31.0 & 0.2 \\
\hline Se & $<0.187$ & 1 \\
\hline Ag & $<1.48$ & 5 \\
\hline-- & -- & UHC $^{\mathbf{b}}$ \\
\hline Sb & $<30.8$ & 1.15 \\
\hline Be & $<0.204$ & 1.22 \\
\hline $\mathrm{Ni}$ & $<3.15$ & 11 \\
\hline Tl & $<0.0484$ & 0.20 \\
\hline-- & (mg/kg) & (mg/kg) \\
\hline benzene & $<0.150$ & 10 \\
\hline phenol & $<10.0$ & 6.2 \\
\hline cyanide (total) & NM & 590 \\
\hline cyanide (amenable) & NM & 30 \\
\hline
\end{tabular}

NM - Not Measured

a SCHWMR R.61-79.261.24(b) “Characteristic of Toxicity.”

b SCHWMR R.61-79.268.48 "Universal Treatment Standards.”

Table 2-2 Customer Recommended Values for Preparation of TCLP Sample

\begin{tabular}{|c||c|}
\hline Parameter & 3QCY12 \\
\hline Water-to-Premix ratio & 0.59 \\
\hline (Daratard 17) gal/Ton premix & 0 \\
\hline $\begin{array}{c}\text { (Dow Corning Q2-3183A) gal/Ton } \\
\text { premix }\end{array}$ & 0.20 \\
\hline
\end{tabular}


Saltstone Mix Data Sheet

\begin{tabular}{|c|c|c|c|}
\hline \multicolumn{2}{|l|}{ MIX \# 0142} & \multicolumn{2}{|c|}{ Date: $\quad 8 / 13 / 2012$} \\
\hline Material & $\%$ & WT\% & Grams \\
\hline Waste Solution: Tank 50 7/17/12 3Q12 & & \multirow{3}{*}{44.89} & \multirow{3}{*}{250.10} \\
\hline Wt\% Solids \# 27.38 & & & \\
\hline Grams Water 181.62 & & & \\
\hline Admixture: $\quad \underline{\text { Q2 Antifoam }}{ }^{*}$ & & 0.03 & 0.08 \\
\hline Admixture: & & & 0.00 \\
\hline \multicolumn{4}{|l|}{ Admixture: } \\
\hline Premix & & 55.10 & 307.00 \\
\hline Cement (\% of Premix) & 10 & 5.51 & 30.70 \\
\hline Slag (\% of Premix) & 45 & 24.79 & 138.15 \\
\hline Fly Ash (\% of Premix) & 45 & 24.79 & 138.15 \\
\hline Total & 100 & 100.01 & 557.18 \\
\hline Water to Premix Ratio & \multicolumn{2}{|c|}{0.59} & \\
\hline \multicolumn{4}{|l|}{$\begin{array}{l}\text { Calculations: } \\
\text { Use CBO fly ash }\end{array}$} \\
\hline \multicolumn{4}{|l|}{$\begin{array}{l}\text { From customer: } \\
0.59 \text { W/P } \\
\text { 0.11 gpm Q2 } \\
\text { 33 TPH Dry Feeds } \\
\text { NO Daratard }\end{array}$} \\
\hline \multicolumn{4}{|c|}{$\begin{array}{l}\text { Q2 is diluted Q2 amount . In plant, diluted } 1: 4 \text { in water. } \\
\text { * Actual amount of Q2 added to sample is } 0.078 \mathrm{~g} \text {. Q2 was diluted to a } 1: 4 \text { in water and } 100 \mathrm{uL} \\
\text { pipette was used to add the diluted Q2 to the sample. }\end{array}$} \\
\hline
\end{tabular}

Figure 2-2 Data sheet for the Saltstone mix used to prepare the 3QCY12 TCLP sample ${ }^{\mathbf{v}}$ 
SRNL-STI-2012-00703

Revision 0

\subsection{Saltstone Testing}

Saltstone testing was performed by B\&W TSG-RACL and GEL Laboratories, LLC. Activities associated with the 3QCY12 saltstone samples were:

At B\&W TSG-RACL,

- TCLP extraction,

- TCLP leachate digestion, and

- digested leachate analysis.

At GEL

- extraction of solid subsamples shipped from B\&W TSG-RACL and

- extract analyses.

\subsubsection{B\&W TSG-RACL}

The samples arrived at B\&W TSG-RACL on September 21, 2012 for analysis. Shipping container temperatures were documented to be $15^{\circ} \mathrm{C}$. The samples were delivered with proper chain of custody documentation and signatures. All sample containers arrived without any visible signs of tampering or breakage.

The Metals method 6020A analysis was performed on an X-7 Series Inductively Coupled Plasma - Mass Spectrometer (ICP-MS). The Metals method 7470A analysis was performed on a Leman PC 200 II instrument which consists of a cold vapor atomic absorption spectrometer (CVAA) set to detect mercury at a wavelength of $253.7 \mathrm{~nm}$.

A portion of the leachate from the third quarter sample was used as the quality control sample (matrix spike) for the ICP-MS and CVAA.

\subsubsection{GEL Laboratories, LLC}

The subsamples arrived at GEL Laboratories, LLC on September 27, 2012 for analysis. Shipping container temperatures were documented to be within EPA specifications. All sample containers arrived without any visible signs of tampering or breakage. The chain of custody documentation was not relinquished. The method 8260B analysis was performed with an HP6890/HP5973 gas chromatograph/mass spectrometer using a Restek RTX-624 column. Methods 9012A and 9066 were performed using a Lachat QuickChem FIA+ 8000 Series.

\subsection{Results and Discussion}

The results summarized in the following tables are from the data package for these analyses. ${ }^{\text {vi }}$ Data are presented in these results as reported by the vendors.

\subsection{B\&W TSG-RACL}

Analytes detected but at concentrations too low to determine quantitatively have been flagged with the "B" qualifier. Analytes that were not detected have been flagged with the " $U$ " qualifier. In addition to the results, Detection Limits (DLs) have been given. The DL is the minimum concentration of an analyte that can be identified, measured, and reported with $99 \%$ confidence that the concentration is above zero. The DL values given in the table are the results from this study adjusted for sample dilution. The Quantitation Limit (QL) is the lowest level at which an analyte may be accurately and reproducibly measured. 
Results in Table 3-1, when compared with the DLs and QLs, can be organized into three groups:

- Beryllium, silver, cadmium, and thallium were not detected in the leachate.

- Antimony, nickel, and lead were detected below the QLs.

- Arsenic, barium, chromium, mercury, and selenium were detected in the leachates at concentrations above the QLs.

Table 3-1 TCLP Leachates RCRA Metal Concentrations, DLs, and QLs

\begin{tabular}{|c||c||c||c||c||c||}
\hline - & Methods & $\begin{array}{c}\text { Sample } \\
\text { Limits } \\
(\mu \mathbf{g} / \mathbf{L})\end{array}$ & $\begin{array}{c}\text { Sample } \\
\text { Limits } \\
(\boldsymbol{\mu g} / \mathbf{L})\end{array}$ & $\begin{array}{c}\text { Sample } \\
\text { Results } \\
(\boldsymbol{\mu g} / \mathbf{L})\end{array}$ & Footnotes \\
\hline SRS ID & - & - & - & $\mathbf{3 Q 1 2}$ & - \\
\hline B\&W ID & - & $\mathbf{D L}$ & $\mathbf{Q L}$ & $\begin{array}{c}\mathbf{1 2 0 9 0 1 3} \\
\mathbf{0 1 R E I}-\mathbf{A}\end{array}$ & - \\
\hline \hline $\mathbf{S b}$ & $3015,6020 \mathrm{~A}$ & 0.556 & 10.000 & 8.44 & $\mathrm{~B}$ \\
\hline $\mathbf{A s}$ & $3015,6020 \mathrm{~A}$ & 0.556 & 5.000 & 43.9 & - \\
\hline $\mathbf{B a}$ & $3015,6020 \mathrm{~A}$ & 5.56 & 50.000 & 212 & - \\
\hline $\mathbf{C d}$ & $3015,6020 \mathrm{~A}$ & 0.556 & 5.000 & 0.556 & $\mathrm{U}$ \\
\hline $\mathbf{C r}$ & $3015,6020 \mathrm{~A}$ & 0.556 & 10.000 & 11.5 & - \\
\hline $\mathbf{P b}$ & $3015,6020 \mathrm{~A}$ & 0.556 & 5.000 & 1.13 & $\mathrm{~B}$ \\
\hline $\mathbf{H g}$ & $7470 \mathrm{~A}$ & 0.029 & 0.200 & 11.6 & - \\
\hline $\mathbf{S e}$ & $3015,6020 \mathrm{~A}$ & 5.56 & 25.000 & 62.4 & - \\
\hline $\mathbf{A g}$ & $3015,6020 \mathrm{~A}$ & 0.556 & 5.000 & 0.556 & $\mathrm{U}, \mathrm{N}$ \\
\hline $\mathbf{B e}$ & $3015,6020 \mathrm{~A}$ & 0.556 & 5.000 & 0.556 & $\mathrm{U}$ \\
\hline $\mathbf{N i}$ & $3015,6020 \mathrm{~A}$ & 0.556 & 5.000 & 1.88 & $\mathrm{~B}$ \\
\hline $\mathbf{T l}$ & $3015,6020 \mathrm{~A}$ & 0.556 & 5.000 & 0.556 & $\mathrm{U}$ \\
\hline
\end{tabular}

- Indicates a location in the table for which an entry would not be appropriate.

${ }^{\mathrm{U}}$ Final concentration of the analyte was found to be below the DL.

${ }^{\text {B }}$ Analyte is present at a concentration above the DL but less than the QL

${ }^{\mathrm{N}}$ Associated Matrix Spike is outside percent recovery quality control criteria.

\subsubsection{Comparison of Results to Regulatory Limits}

Results from the TCLP leachate analyses from Table 3-1 are replicated in Table 3-2 - with units changed from $\mu \mathrm{g} / \mathrm{L}$ to $\mathrm{mg} / \mathrm{L}$-along with the regulatory limits that may be applied to the Saltstone waste form. Table 3-2 includes the SCHWMR R.61-79.261.24(b) limits above which a waste is to be considered characteristically hazardous for toxicity and the SCHWMR R.6179.268.48 Universal Treatment Standards (UTS) for hazardous constituents. In addition, Maximum Contaminant Levels (MCL's) from the State Primary Drinking Water Regulations ${ }^{\mathrm{i}}$ also have been included in Table 3-2. By comparing the sample results and the regulatory limits the following conclusions can be made:

- The saltstone waste form was not characteristically hazardous for toxicity.

- The leachate metals concentrations were below the Nonwastewater Standard for all of the metals.

- Barium, beryllium, cadmium, chromium, lead, silver, and thallium were below the MCL's.

- Antimony, arsenic, mercury, and selenium exceeded the MCL.

- Nickel does not have a MCL. 
The MCL is the limit for a constituent in drinking water. The MCL is used to determine the class of landfill required. At 10x MCL, a Class 3 landfill is required. The SDF vaults are permitted as a Class 3 landfill. None of the analyses were greater than 10x the MCL.

Table 3-2 Saltstone TCLP Results and Corresponding Regulatory Limits

\begin{tabular}{|c|c|c|c|c|c|}
\hline- & Sample Results (mg/L) & Footnotes & \multicolumn{3}{|c|}{ Regulatory Limits } \\
\hline SRS ID & \multicolumn{2}{|l|}{ 3QCY12 } & Toxicity $^{\mathrm{a}}$ & UTS $^{\mathbf{b}}$ & $\mathrm{MCL}^{\mathrm{c}}$ \\
\hline B\&W ID & \multicolumn{2}{|c|}{ 1209013-01RE1-A } & $(\mathrm{mg} / \mathrm{L})$ & $\begin{array}{c}\text { Nonwastewater } \\
\text { Standard } \\
\text { (mg/L TCLP) }\end{array}$ & $(\mathrm{mg} / \mathrm{L})$ \\
\hline Sb & 8.44E-03 & B & - & 1.15 & 0.006 \\
\hline As & 4.39E-02 & - & 5 & 5 & 0.010 \\
\hline $\mathbf{B a}$ & $2.12 \mathrm{E}-01$ & - & 100 & 21 & 2 \\
\hline Cd & $5.56 \mathrm{E}-04$ & $\mathrm{U}$ & 1 & 0.11 & 0.005 \\
\hline $\mathrm{Cr}$ & 1.15E-02 & - & 5 & 0.6 & 0.1 \\
\hline $\mathbf{P b}$ & $1.13 \mathrm{E}-03$ & $\mathrm{~B}$ & 5 & 0.75 & $0.015^{\mathrm{d}}$ \\
\hline $\mathrm{Hg}$ & $1.16 \mathrm{E}-02$ & - & 0.2 & 0.025 & 2E-03 \\
\hline Se & $6.24 \mathrm{E}-02$ & - & 1 & 5.7 & 0.05 \\
\hline Ag & $5.56 \mathrm{E}-04$ & U,N & 5 & 0.14 & $0.1^{\mathrm{e}}$ \\
\hline Be & $5.56 \mathrm{E}-04$ & $\mathrm{U}$ & - & 1.22 & $4 \mathrm{E}-03$ \\
\hline $\mathbf{N i}$ & $1.88 \mathrm{E}-03$ & $\mathrm{~B}$ & - & 11 & - \\
\hline Tl & $5.56 \mathrm{E}-04$ & $\mathrm{U}$ & - & 0.20 & $2 \mathrm{E}-03$ \\
\hline
\end{tabular}

- Indicates a location in the table for which an entry would not be appropriate.

${ }^{\mathrm{U}}$ Final concentration of the analyte was found to be below the DL.

B Analyte is present at a concentration above the DL but less than the QL.

${ }^{\mathrm{N}}$ Associated Matrix Spike is outside percent recovery quality control criteria

a R.61-79.261.24(b) "Characteristic of Toxicity."

${ }^{\mathrm{b}}$ R.61-79.268.48 "Universal Treatment Standards.”

' SCDHEC State Primary Drinking Water Regulation Maximum Contaminant Levels.

${ }^{\mathrm{d}}$ Lead action level from SCDHEC 61-58.11.B.

${ }^{\mathrm{e}}$ Secondary drinking water parameter.

\subsubsection{Quality Assurance}

The following subsections include summaries of results from blanks, laboratory control samples, matrix spikes, and matrix spike duplicates. The data package also includes data for calibration verifications, interference checks, and serial dilutions. ${ }^{\text {vii }}$

\section{Blanks}

Blank concentrations are given in Table 3-3. In the TCLP Blank, nickel, and selenium were present at levels above the quantitation limit. Arsenic, barium, chromium, and lead were present at levels above their respective DLs, but below their respective QLs. Antimony, beryllium, cadmium, mercury, silver, and thallium were found to be below the DLs. 
Table 3-3 TCLP Blank

\begin{tabular}{|c|c|c||}
\hline Analyte & TCLP Blank $(\mu \mathrm{g} / \mathbf{L})$ & Footnotes \\
\hline \hline $\mathbf{S b}$ & 0.556 & $\mathrm{U}$ \\
\hline $\mathbf{A s}$ & 2.89 & $\mathrm{~B}$ \\
\hline $\mathbf{B a}$ & 6.42 & $\mathrm{~B}$ \\
\hline $\mathbf{C d}$ & 0.556 & $\mathrm{U}$ \\
\hline $\mathbf{C r}$ & 1.68 & $\mathrm{~B}$ \\
\hline $\mathbf{P b}$ & 2.97 & $\mathrm{~B}$ \\
\hline $\mathbf{H g}$ & 0.029 & $\mathrm{U}$ \\
\hline $\mathbf{S e}$ & 34.4 & - \\
\hline $\mathbf{A g}$ & 0.556 & $\mathrm{U}, \mathrm{N}$ \\
\hline $\mathbf{B e}$ & 0.556 & $\mathrm{U}$ \\
\hline $\mathbf{N i}$ & 11.3 & - \\
\hline $\mathbf{T l}$ & 0.556 & $\mathrm{U}$ \\
\hline
\end{tabular}

${ }^{\mathrm{B}}$ Analyte is present at a concentration above the DL but less than the QL.

${ }^{\mathrm{U}}$ Final concentration of the analyte was found to be below the DL.

\section{Laboratory Control Samples}

Results from the Laboratory Control Sample (LCS) are given in Table 3-4. The LCS post spike recoveries met USEPA SW-846 acceptance limits for all elements except for mercury. Laboratory Control Samples are clean aqueous solutions analyzed to assure integrity of the analytical technique exclusive of matrix effects.

Table 3-4 RCRA Metal Laboratory Control Sample

\begin{tabular}{|c||c|c|c||}
\hline \hline \multicolumn{1}{|c||}{ Analyte } & \multicolumn{2}{|c|}{ Laboratory Control $(\boldsymbol{\mu g} / \mathbf{L})$} & Recovery (\%) \\
\hline- & True & Measured & $(80-120)$ \\
\hline \hline Sb & 273 & 248 & 91 \\
\hline $\mathbf{A s}$ & 386 & 352 & 91 \\
\hline $\mathbf{B a}$ & 1440 & 1300 & 90 \\
\hline $\mathbf{C d}$ & 350 & 310 & 89 \\
\hline $\mathbf{C r}$ & 79 & 74 & 94 \\
\hline $\mathbf{P b}$ & 1480 & 1350 & 91 \\
\hline $\mathbf{H g}$ & 6.2 & 9.15 & 147.6 \\
\hline $\mathbf{S e}$ & 747 & 654 & 88 \\
\hline $\mathbf{A g}$ & 286 & 261 & 91 \\
\hline $\mathbf{B e}$ & 177 & 156 & 88 \\
\hline $\mathbf{N i}$ & 2370 & 2190 & 92 \\
\hline $\mathbf{T l}$ & 822 & 704 & 86 \\
\hline
\end{tabular}




\section{Matrix Spikes}

Results from analysis of the matrix spike (MS) and matrix spike duplicates (MSD) are given in Table 3-5. The initial concentrations in the second column are reproduced from Table 3-1. These results show that:

- The percent recoveries (\%R) obtained from the MS analyses met the recommended quality control acceptance criteria for percent recoveries (75 - 125\%) for all applicable analytes except silver.

- The percent recoveries (\%R) obtained from the MSD analyses met the recommended quality control acceptance criteria for percent recoveries (75 - 125\%) for all applicable analytes except silver.

- The RPD(s) between the MS and MSD met the acceptance limits (0 - 20\%).

Table 3-5 TCLP Leachates RCRA Metal Matrix Spike and Duplicate Results

\begin{tabular}{|c|c|c|c|c|c|c|c|c|}
\hline \multirow{2}{*}{$\begin{array}{c}\text { Analyte } \\
-\end{array}$} & \multicolumn{3}{|c|}{$\begin{array}{c}\text { Initial Concentrations } \\
(\mu \mathrm{g} / \mathrm{L})\end{array}$} & \multicolumn{2}{|c|}{$\begin{array}{c}\text { Spiked Sample } \\
(\mu \mathrm{g} / \mathrm{L})\end{array}$} & \multicolumn{2}{|c|}{ Recovery (\%) } & \multirow{2}{*}{$\begin{array}{c}\text { RPD } \\
\text { (\%) } \\
-\end{array}$} \\
\hline & $\begin{array}{l}\text { B\&W ID } \\
\text { 1112002- } \\
\text { 01RE1-A } \\
\end{array}$ & Footnotes & $\begin{array}{l}\text { Spike } \\
\text { Added }\end{array}$ & Spike & $\begin{array}{c}\text { Spike } \\
\text { Duplicate }\end{array}$ & Spike & $\begin{array}{c}\text { Spike } \\
\text { Duplica } \\
\text { te }\end{array}$ & \\
\hline Sb & 8.44 & $\mathrm{~B}$ & 978 & 993 & 992 & 101 & 101 & 0.10 \\
\hline As & 43.9 & - & 490 & 565 & 559 & 106 & 105 & 1.07 \\
\hline $\mathbf{B a}$ & 212 & - & 2450 & 2760 & 2780 & 104 & 105 & 0.72 \\
\hline Cd & 0.556 & $\mathrm{U}$ & 245 & 221 & 222 & 90 & 91 & 0.45 \\
\hline $\mathrm{Cr}$ & 11.5 & - & 978 & 957 & 962 & 97 & 97 & 0.52 \\
\hline $\mathbf{P b}$ & 1.13 & B & 490 & 542 & 541 & 110 & 110 & 0.18 \\
\hline $\mathrm{Hg}$ & 11.6 & - & 4.90 & 16.7 & 16.9 & 104.1 & 108.2 & 1.2 \\
\hline Se & 62.4 & - & 245 & 310 & 315 & 101 & 103 & 1.60 \\
\hline Ag & 0.556 & $\mathrm{U}$ & 245 & 69 & 60 & 28 & 24 & 13.95 \\
\hline Be & 0.556 & $\mathrm{U}$ & 245 & 227 & 227 & 93 & 93 & 0.00 \\
\hline $\mathbf{N i}$ & 1.88 & B & 978 & 874 & 878 & 89 & 90 & 0.46 \\
\hline $\mathbf{T l}$ & 0.556 & $\mathrm{U}$ & 245 & 262 & 262 & 107 & 107 & 0.00 \\
\hline
\end{tabular}

${ }^{\mathrm{U}}$ Final concentration of the analyte was found to be below the DL.

${ }^{B}$ Analyte is present at a concentration above the DL but less than the QL.

\section{Calibration Information}

- All initial calibration requirements have been met for this sample delivery group (SDG).

- All Contract Required Reporting Limit requirement(s) met the referenced advisory control limits with the exception of selenium.

- All interference check samples associated with this SDG met the established acceptance criteria. 
- All continuing calibration blanks bracketing this batch met the established acceptance criteria except for thallium and selenium which were $>3$ times the current IDL.

- All continuing calibration verifications bracketing this SDG met the acceptance criteria.

\subsection{GEL Laboratories, LLC}

GEL reports general chemistry analyses on the organics in the sample. If the concentrations of benzene, phenol, and cyanide are not detected or are below the detection limit ( $<\mathrm{MDL})$ the result is reported as "ND". Analytes detected but at concentrations too low to determine quantitatively have been flagged with the "J" qualifier. Analytes that were not detected have been flagged with the "U" qualifier. In addition to the results, Detection Limits (DLs) and Reporting Limits (RLs) have been given. The DL is the minimum concentration of an analyte that can be identified, measured, and reported with $99 \%$ confidence that the concentration is above zero. The DL values given in Table 3-6 are the results from this study adjusted for sample dilution. The RL is the lowest level at which an analyte may be accurately and reproducibly quantitated.

Table 3-6 Total Concentrations, DLs, and RLs

\begin{tabular}{|c||c||c||c||c||}
\hline- & Methods & $\begin{array}{c}\text { Sample } \\
\text { Limits } \\
(\mu \mathrm{g} / \mathrm{kg})\end{array}$ & $\begin{array}{c}\text { Sample } \\
\text { Limits } \\
(\mu \mathrm{g} / \mathrm{kg})\end{array}$ & $\begin{array}{c}\text { Sample } \\
\text { Results* } \\
(\mu \mathrm{g} / \mathrm{kg})\end{array}$ \\
\hline SRS ID & - & - & - & $\mathbf{3 Q C Y 1 2}$ \\
\hline GEL ID & - & $\mathbf{D L}$ & $\mathbf{R L}$ & $\mathbf{3 1 2 0 4 4 0 0 1}$ \\
\hline Benzene & $5030,8260 \mathrm{~B}$ & 30.0 & 100 & ${ }^{\mathrm{N} D}$ \\
\hline Phenol & $9010 \mathrm{~B}, 9066$ & 78.6 & 236 & ${ }^{\mathrm{J}} 82.1$ \\
\hline $\begin{array}{c}\text { Cyanide } \\
\text { (total) }\end{array}$ & $9010 \mathrm{~B}, 9012 \mathrm{~A}$ & 75.9 & 227 & 7860 \\
\hline $\begin{array}{c}\text { Cyanide } \\
\text { (amenable })\end{array}$ & $9012 \mathrm{~A}$ & 159 & 477 & ${ }^{\mathrm{N} D}$ \\
\hline \hline
\end{tabular}

- Indicates a location in the table for which an entry would not be appropriate.

${ }^{\mathrm{J}}$ Analyte is present at a concentration above the DL but less than the RL.

${ }^{\mathrm{U}}$ Final concentration of the analyte was found to be below the DL.

\subsubsection{Comparison of Results to Regulatory Limits}

Results from the analyses from Table 3-6 are replicated in Table 3-7 - with units changed from $\mu \mathrm{g} / \mathrm{kg}$ to $\mathrm{mg} / \mathrm{kg}$ - along with the regulatory limits that may be applied to the Saltstone waste form. Table 3-7 includes the SCHWMR R.61-79.268.48 Universal Treatment Standards (UTS) for hazardous constituents. By comparing the sample results and the regulatory limits in Table $3-7$, it can be concluded that for all of the analytes, the concentrations were below the Nonwastewater Standard. 
SRNL-STI-2012-00703

Revision 0

Table 3-7 Saltstone Total Results and Corresponding Regulatory Limits

\begin{tabular}{||c||c|c||}
\hline- & $\begin{array}{c}\text { Sample } \\
\text { Results } \\
(\mathbf{m g} / \mathbf{k g})\end{array}$ & $\begin{array}{c}\text { Regulatory Limits } \\
(\mathbf{m g} / \mathbf{k g})\end{array}$ \\
\hline SRS ID & $3 \mathrm{QQCY} 12$ & \multirow{2}{*}{ UTS $^{\mathbf{b}}$} \\
\hline GEL ID & 312044001 & \\
\hline Benzene & ${ }^{\mathrm{U}} \mathrm{ND}$ & 10 \\
\hline Phenol & ${ }^{\mathrm{J}} 0.0821$ & 6.2 \\
\hline Cyanide (total) & 7.860 & 590 \\
\hline Cyanide (amenable) & ${ }^{\mathrm{U}} \mathrm{ND}$ & 30 \\
\hline
\end{tabular}

- Indicates a location in the table for which an entry would not be appropriate.

${ }^{\mathrm{J}}$ Analyte is present at a concentration above the DL but less than the RL.

${ }^{\mathrm{U}}$ Final concentration of the analyte was found to be below the DL.

${ }^{\mathrm{b}}$ R.61-79.268.48 “Universal Treatment Standards”.

ND - Not Detectable

\subsubsection{Quality Assurance}

The following subsections include summaries of results from blanks, laboratory control samples, matrix spikes, and matrix spike duplicates. The data package for this task also includes data for calibration verifications, interference checks, and serial dilutions.

\section{Blanks}

Blank concentrations are given in Table 3-8. Amenable to chlorination cyanide is determined by subtracting the results determined in the chlorinated cyanide test from those determined in the total cyanide test. The Method Blanks analyzed with this Sample Delivery Group (SDG) met the acceptance criteria.

Table 3-8 Method Blank

\begin{tabular}{|c||c||}
\hline Analyte & \multicolumn{2}{|c|}{ Method Blank $(\boldsymbol{\mu g} / \mathbf{k g})$} \\
\hline \hline Benzene & ${ }^{\mathrm{U}} \mathrm{ND}$ \\
\hline Phenol & ${ }^{\mathrm{U} N D}$ \\
\hline Cyanide (total) & ${ }^{\mathrm{U} N D}$ \\
\hline Cyanide (amenable) & -- \\
\hline
\end{tabular}

- Indicates a location in the table for which an entry would not be appropriate.

${ }^{\mathrm{U}}$ Final concentration of the analyte was found to be below the DL.

ND - Not Detectable

\section{Laboratory Control Samples}

Results from the Laboratory Control Sample (LCS) are given in Table 3-9. All LCS recoveries met the vendor laboratory acceptance. Laboratory Control Samples are clean aqueous solutions analyzed to assure integrity of the analytical technique exclusive of matrix effects. 
SRNL-STI-2012-00703

Revision 0

Table 3-9 Laboratory Control Sample

\begin{tabular}{|c|c|c|c|c|c|}
\hline Analyte & \multicolumn{3}{|c|}{$\begin{array}{c}\text { Laboratory Control } \\
(\mu \mathrm{g} / \mathrm{kg})\end{array}$} & \multirow{2}{*}{\multicolumn{2}{|c|}{$\begin{array}{c}\text { Recovery (\%) } \\
-\end{array}$}} \\
\hline- & True & Med & ured & & \\
\hline Benzene & 50.0 & \multicolumn{2}{|c|}{44.1} & \multicolumn{2}{|c|}{88.2} \\
\hline Phenol & 2500 & 2530 & 2310 & 101 & 92.2 \\
\hline Cyanide (total) & 28100 & 29500 & 30800 & 105 & 109 \\
\hline Cyanide (amenable) & -- & \multicolumn{2}{|c|}{-- } & \multicolumn{2}{|c|}{-} \\
\hline
\end{tabular}

- Indicates a location in the table for which an entry would not be appropriate.

\section{Matrix Spikes}

Total cyanide is the only method where a matrix spike would be applicable. However, GEL reported that due to the highly radioactive and/or hazardous matrix of samples in the batch, matrix QC was not performed.

\section{Calibration Information}

- All initial calibration requirements have been met for this sample delivery group (SDG).

- All Contract Required Detection Limit standard(s) met the referenced advisory control limits.

- All interference check samples associated with this SDG met the established acceptance criteria.

- All continuing calibration blanks bracketing this batch met the established acceptance criteria.

- All continuing calibration verifications bracketing this SDG met the acceptance criteria.

\subsection{Conclusions}

Preparation of the 3QCY12 saltstone samples and the subsequent TCLP analyses showed that:

- The saltstone waste form disposed of in the Saltstone Disposal Facility in 3QCY12 was not characteristically hazardous for toxicity.

- The concentrations of the eight RCRA metals and UHCs identified as possible in the saltstone waste form were present at levels below the UTS.

- Analyses met all quality assurance specifications of USEPA SW-846.

The saltstone waste form placed in the Saltstone Disposal Facility in 3QCY12 met the SCHWMR R.61-79.261.24(b) RCRA metals requirements for a nonhazardous waste form. The TCLP leachate concentrations were less than 10x the MCLs in SCDHEC Regulations R.61-107.19, Part I C.

The saltstone waste form placed in the Saltstone Disposal Facility in 3QCY12 met the R.6179.268.48(a) non wastewater treatment standards.

Analyses met all USEPA SW-846 quality assurance requirements. All other limits on holding times, laboratory control sample recoveries, matrix spike recoveries, serial dilution results when 
SRNL-STI-2012-00703

Revision 0

applicable, calibration verification, and interference checks were within the quality assurance requirements 
SRNL-STI-2012-00703

Revision 0

\subsection{References}

i. Liner, K. R. Saltstone Grout Sampling (U), ESH-EPG-2004-00318, Savannah River Site, 2004.

ii. Toxicity Characteristic Leaching Procedure. EPA SW-846, Procedure 1311.

iii. Britt, T. E. Assessment of Regulated Oganics Under 40 CFR Part 268, Section 49, Universal Treatment Standards, Relative to SRS Tank Farm Waste, LWO-LWE-2007-00052, Savannah River Site, 2007.

iv. Bannochie, C. J. Tables Containing Results for the Third Quarter 2012 Tank 50 WAC Sample: Chemical and Radionuclide Contaminant Results, SRNL-L3100-2012-00144, Rev 1. Savannah River Site, October 2012.

v. Reigel, M. N. Saltstone TCLP, SRNL-NB-2009-00076, Savannah River Site.

vi. Liner, K. R. Sampling and Analysis Plan for the Z-Area Industrial Solid Waste Landfill Disposal Facility During Interim Salt Waste Processing (U), EXH-WPG-2005-00039, Savannah River Site, 2005

vii. Eibling, R. E.. Data Package From Vendor for 3QCY12 TCLP Analysis, SRNL-L3100-201200189, Rev. 0, Savannah River Site, October 2012. 


\section{Distribution:}

\begin{tabular}{|l|l|}
\hline Name: & Location: \\
\hline P. M. Almond & $773-43 \mathrm{~A}$ \\
\hline C. J. Bannochie & $773-42 \mathrm{~A}$ \\
\hline P. L. Bovan & $704-27 \mathrm{~S}$ \\
\hline N. F. Chapman & $766-\mathrm{H}$ \\
\hline J. S. Contardi & $766-\mathrm{H}$ \\
\hline A. D. Cozzi & $999-\mathrm{W}$ \\
\hline C. E. Duffey & $704-61 \mathrm{H}$ \\
\hline R. E. Eibling & $999-\mathrm{W}$ \\
\hline A. D. England & $704-14 \mathrm{Z}$ \\
\hline S. D. Fink & $773-\mathrm{A}$ \\
\hline K. M. Fox & $999-\mathrm{W}$ \\
\hline E. J. Freed & $704-56 \mathrm{H}$ \\
\hline B. J. Giddings & $786-5 \mathrm{~A}$ \\
\hline J. C. Griffin & $773-\mathrm{A}$ \\
\hline E. K. Hansen & $999-\mathrm{W}$ \\
\hline C. C. Herman & $999-\mathrm{W}$ \\
\hline P. J. Hill & $766-\mathrm{H}$ \\
\hline P. R. Jackson & $703-46 \mathrm{~A}$ \\
\hline M. T. Keefer & $704-56 \mathrm{H}$ \\
\hline C. A. Langton & $773-43 \mathrm{~A}$ \\
\hline J. N. Leita & $704-30 \mathrm{~S}$ \\
\hline K. R. Liner & $704-\mathrm{S}$ \\
\hline M. J. Mahoney & $766-\mathrm{H}$ \\
\hline S. L. Marra & $773-\mathrm{A}$ \\
\hline D. J. Martin & $241-246 \mathrm{H}$ \\
\hline P. W. Norris & $704-\mathrm{Z}$ \\
\hline E. Patten & $704-\mathrm{Z}$ \\
\hline F. M. Pennebaker & $773-42 \mathrm{~A}$ \\
\hline J. W. Ray & $704-\mathrm{S}$ \\
\hline M. M. Reigel & $999-\mathrm{W}$ \\
\hline L. B. Romanowski & $766-\mathrm{H}$ \\
\hline E. R. Seldon & $704-\mathrm{Z}$ \\
\hline A. R. Shafer & $704-27 \mathrm{~S}$ \\
\hline F. M. Smith & $705-1 \mathrm{C}$ \\
\hline A. V. Staub & $704-\mathrm{Z}$ \\
\hline K. H. Subramanian & $249-8 \mathrm{H}$ \\
\hline B. C. Terry & $735-\mathrm{B}$ \\
\hline & \\
\hline
\end{tabular}

